\section{INSTRUMENTS FOR SQUINTING.}

\section{To the Editor of THE LANCET.}

SIR:-So many instruments have been described for performing the operation for the cure of strabismus, that $I$ feel it almost necessary to offer an apology when I re. commend a new instrument, which $I$ have found most serviceable in operations performed by myself.

The instrument $I$ have to recommend dif. fers from that used by $\mathrm{Mr}$. French, in having the straight part of it between the hook and the handle made with a free. cutting edge, upon which the muscle is divided after it has been taken up by the hook, which in my instrument has a blunt edge.

In my own operations, as well as in those which I have seen performed by others, I have observed that the hook when made with a cutting edge has been quite insufficient to complete the section of the muscle; in short, instead of cutting its way out, and thus falfilling the object for which it was made, it has in most instances re. quired to be cut out with the assistance of the scissors. But when the knife here de. scribed is used no scissors are required; the muscle is made to glide over the blunt hook on to the straight-cutting part, to which a sawing motion can be readily given, and the division of the muscle is soon completed.

In the operations which I have usually seen performed, care has not been taken to bring out the point of the hook by the same opening in the conjunctiva which was made to introduce it; on the contrary, the point of the hook after passing under the muscle, has been brought out by a new opening rnade higher up than the original one. By this procedure nearly as much of the conjunctiva is divided as in those operations, where, by means of the scissors and forceps, the muscle and conjunctiva, together with the fat and cellular tissue connecting them, are clearly and extensively removed from the inner part of the eyeball.

The operation performed in either of these ways is liable to the serious objection, that the eyeball liberated so extensively from its attachment is too frequently found to protrude in a degree amounting to deformity. I have the honour to be, Sir, your obedient servant,

\section{A. Farquhar.}

19, Albemarle-street, Sept. 24, 1840.
CORRESPONDENCE

OF THE

BRITISH MEDICAL ASSOCIATION WITH LORD JOHN RUSSELL, RELATIVE TO THE

\section{REMUNERATION OF MEDICAL OFFICERS}

UNDER THE POOR-LAW.

Downing-street, May 20, 1840.

Sir :-In reference to your communication of the 11 th instant, I am desired by Lord John Russell to inform you, that if it would be convenient to you, he would be much obliged to you if you could put before him in writing the suggestions you desire to make to him in an interview, relative to the remuneration of medical officers under the poor-law, as his time is very much occupied by the pressure of parliamentary and other public business. For this reason, also, I regret that an answer has not been sooner returned to your letter. I am, Sir, your obedient servant,
(Signed)
C. G. Howard.

To C. H. R. Harrison, Esq.,

18, Southampton-street, Fitzroy-square, May 29, 1840.

My lord, in compliance with the request which your lordship was pleased to make in your note of the 20th of May inst, and addressed to me by your lordship's command, the council of the British Medical Association beg to submit to your lordship the following suggestions relative to medical attendance upon the poor.

The poor-law commissioners have admitted the imperfection of the present system; they have stated their "present views as to medical relief" in their last report, and say that they shall be prepared "to take the necessary steps to give them effect, unless Parliament should lay down any other course which may be deemed preferable."

The British Medical Association coincides with many of the views of the poor-law commissioners, as they are, in fact, based upon the evidence of the medical witnesses before the parliamentary committee.

Without, however, expressing any distrust of the good intentions of the poor-law commissioners, or implying the least disrespect, we must state that the medical profession has much greater confidence in your lordship, and in Parliament, than in them; and that it would be more satisfactory to us, and we believe to the poor, if your lordship wonld lay down in the Bill now before Parliament the principles which should regulate medical relief. The control of the detail may be given to the poor-law commissioners; but we respectfully submit to your lordship, that a matter of vital importance to the health of the great mass of the people 